\title{
Front Matter Volume 8624
}

, "Front Matter Volume 8624," Proc. SPIE 8624, Terahertz, RF, Millimeter, and Submillimeter-Wave Technology and Applications VI, 862401 (8 April 2013); doi: $10.1117 / 12.2022480$

SPIE. Event: SPIE OPTO, 2013, San Francisco, California, United States 


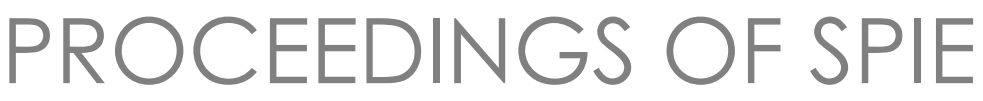

\section{Terahertz, RF, Millimeter, and Submillimeter-Wave Technology and Applications VI}

Laurence P. Sadwick Créidhe M. O'Sullivan Editors

5-7 February 2013

San Francisco, California, United States

Sponsored and Published by

SPIE 
The papers included in this volume were part of the technical conference cited on the cover and title page. Papers were selected and subject to review by the editors and conference program committee. Some conference presentations may not be available for publication. The papers published in these proceedings reflect the work and thoughts of the authors and are published herein as submitted. The publisher is not responsible for the validity of the information or for any outcomes resulting from reliance thereon.

Please use the following format to cite material from this book:

Author(s), "Title of Paper," in Terahertz, RF, Millimeter, and Submillimeter-Wave Technology and Applications VI, edited by Laurence P. Sadwick, Créidhe M. O'Sullivan, Proceedings of SPIE Vol. 8624 (SPIE, Bellingham, WA, 2013) Article CID Number.

ISSN: 0277-786X

ISBN: 9780819493934

Published by

SPIE

P.O. Box 10, Bellingham, Washington 98227-0010 USA

Telephone +1 3606763290 (Pacific Time) · Fax +1 3606471445

SPIE.org

Copyright @ 2013, Society of Photo-Optical Instrumentation Engineers.

Copying of material in this book for internal or personal use, or for the internal or personal use of specific clients, beyond the fair use provisions granted by the U.S. Copyright Law is authorized by SPIE subject to payment of copying fees. The Transactional Reporting Service base fee for this volume is $\$ 18.00$ per article (or portion thereof), which should be paid directly to the Copyright Clearance Center (CCC), 222 Rosewood Drive, Danvers, MA 01923. Payment may also be made electronically through CCC Online at copyright.com. Other copying for republication, resale, advertising or promotion, or any form of systematic or multiple reproduction of any material in this book is prohibited except with permission in writing from the publisher. The CCC fee code is 0277-786X/13/\$18.00.

Printed in the United States of America.

Publication of record for individual papers is online in the SPIE Digital Library.

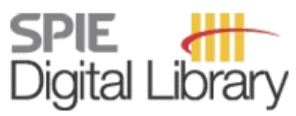

SPIEDigitalLibrary.org

Paper Numbering: Proceedings of SPIE follow an e-First publication model, with papers published first online and then in print and on CD-ROM. Papers are published as they are submitted and meet publication criteria. A unique, consistent, permanent citation identifier (CID) number is assigned to each article at the time of the first publication. Utilization of CIDs allows articles to be fully citable as soon as they are published online, and connects the same identifier to all online, print, and electronic versions of the publication. SPIE uses a six-digit CID article numbering system in which:

- The first four digits correspond to the SPIE volume number.

- The last two digits indicate publication order within the volume using a Base 36 numbering

system employing both numerals and letters. These two-number sets start with 00, 01, 02, 03, 04, $05,06,07,08,09,0 A, 0 B \ldots 0 Z$, followed by 10-1Z, 20-2Z, etc.

The CID Number appears on each page of the manuscript. The complete citation is used on the first page, and an abbreviated version on subsequent pages. Numbers in the index correspond to the last two digits of the six-digit CID Number. 


\title{
Contents
}

\author{
ix Conference Committee \\ xi Introduction \\ xvii Group IV photonics for the mid infrared (Plenary Paper) [8629-1] \\ $R$. Soref, The Univ. of Massachusetts at Boston (United States)
}

xxxiii Light in a twist: optical angular momentum (Plenary Paper) [8637-2]

M. J. Padgett, Univ. of Glasgow (United Kingdom)

\section{THZ TOPICS AND ADVANCEMENTS}

862403 Active THz medical imaging using broadband direct detection (Invited Paper) [8624-2] Z. D. Taylor, J. Garritano, P. Tewari, E. Diebold, S. Sung, N. Bajwa, B. Nowroozi, Univ. of California, Los Angeles (United States); A. Stojadinovic, Walter Reed Army Medical Ctr. (United States) and Combat Wound Initiative Program (United States); N. Llombart, Wright State Univ. (United States); E. R. Brown, Technische Univ. Delft (Netherlands); W. S. Grundfest, Univ. of California, Los Angeles (United States)

THZ AND SUBMILLIMETER GENERATION AND SOURCES

862406 Microfabrication and cold testing of copper circuits for a 50-watt 220-GHz traveling wave tube (Invited Paper) [8624-5]

C. D. Joye, A. M. Cook, J. P. Calame, D. K. Abe, A. N. Vlasov, I. A. Chernyavskiy, U.S. Naval Research Lab. (United States); K. T. Nguyen, E. L. Wright, Beam-Wave Research, Inc. (United States)

862407 A tunable continuous-wave terahertz generator based on 1.3- $\mu \mathrm{m}$ dual-mode laser diode and travelling-wave photodiode [8624-6]

H.-C. Ryu, N. Kim, J.-W. Park, S.-P. Han, H. Ko, K. Moon, Electronics and Telecommunications Research Institute (Korea, Republic of); M. Y. Jeon, Chungnam National Univ. (Korea, Republic of); K. H. Park, Electronics and Telecommunications Research Institute (Korea, Republic of)

862408 Sub-mm/THz wave generation/amplification using Cerenkov-transition based device [8624-7]

A. I. Nashed, S. K. Chaudhuri, S. Safavi-Naeini, Univ. of Waterloo (Canada)

862409 Room temperature generation of THz radiation in GaN quantum wells structures [8624-8] A. Penot, J. Torres, P. Nouvel, L. Varani, Institut d'Electronique du Sud, Univ. Montpellier 2 (France); F. Teppe, C. Consejo, N. Dyakonova, W. Knap, Lab. Charles Coluomb, Univ. Montpellier 2 (France); Y. Cordier, S. Chenot, M. Chmielowska, Ctr. de Recherche sur I'Hétéro-Epitaxie et ses Applications (France); J.-P. Faurie, B. Beaumont, Lumilog (France); P. Shiktorov, E. Starikov, V. Gruzinskis, Semiconductor Physics Institute (Lithuania) 
THZ SMART MATERIALS AND IMAGING

8624 OB Precise manipulation of light properties in optical domain by RF technology (Invited Paper) [8624-49]

T. Yang, Z. Zhang, T. Wang, Z. Wang, Z. Wang, C. Ge, D. Jia, M. Sang, Tianjin Univ. (China)

8624 OC Terahertz time-domain spectroscopy of organic semiconductors [8624-11]

D. M. Hailu, H. Aziz, S. Safavi-Naeini, Univ. of Waterloo (Canada); D. Saeedkia, TeTechS Inc. (Canada)

8624 OD 3D terahertz beam profiling [8624-12]

P. Klarskov, A. C. Strikwerda, T. Wang, M. Zalkovskij, P. U. Jepsen, Technical Univ. of Denmark (Denmark)

$8624 \mathrm{OE} \quad$ Imaging at $\mathbf{0 . 2}$ and $\mathbf{2 . 5}$ terahertz [8624-13]

A. M. Melo, BR Labs. (Brazil); M. A. P. Toledo, Univ. Estadual de Campinas (Brazil);

F. C. B. Maia, A. Rocha, M. B. Plotegher, BR Labs. (Brazil); D. Pereira, F. C. Cruz, Univ. Estadual de Campinas (Brazil)

8624 OF Introducing a 384x288 pixel terahertz camera core [8624-14]

C. Chevalier, L. Mercier, F. Duchesne, L. Gagnon, B. Tremblay, M. Terroux, F. Généreux, J.-E. Paultre, F. Provençal, Y. Desroches, L. Marchese, H. Jerominek, C. Alain, A. Bergeron, INO (Canada)

\section{RF DEVICES, SOURCES, AND COMPONENTS}

$8624 \mathrm{OH}$ Millimeter-wave and sub-millimeter-wave vacuum electronics amplifier development at the US Naval Research Laboratory (Invited Paper) [8624-16]

D. K. Abe, J. P. Calame, C. D. Joye, A. M. Cook, J. A. Pasour, S. Cooke, A. N. Vlasov, I. A. Chernyavskiy, B. Levush, U.S. Naval Research Lab. (United States); K. T. Nguyen, D. E. Pershing, Beam-Wave Research, Inc. (United States); D. Chernin, SAIC (United States)

8624 Ol Integrated RF photonic devices based on crystal ion sliced lithium niobate [8624-17] V. Stenger, J. Toney, A. Pollick, J. Busch, J. Scholl, P. Pontius, S. Sriram, SRICO Inc. (United States)

8624 0J IMDD microwave photonic link modeling using Optsim [8624-18] J. Haefner, T. Copenhaver II, J. Kurka, J. West, M. Maurer, C. Middlebrook, Michigan Technological Univ. (United States)

8624 OK Toward a widely tunable narrow linewidth RF source utilizing an integrated heterogenous silicon photonic module [8624-19]

D. W. Grund Jr., G. A. Ejzak, G. J. Schneider, J. Murakowski, S. Shi, D. W. Prather, The Univ. of Delaware (United States) 
$8624 \mathrm{OL}$ Towards integrated continuous wave THz systems [8624-20]

T. Göbel, D. Stanze, U. Troppenz, J. Kreissl, B. Sartorius, M. Schell, Fraunhofer-Institut für Nachrichtentechnik Heinrich-Hertz-Institut (Germany)

8624 OM Widely tunable opto-electronic oscillator based on a dual frequency laser [8624-21] J. Maxin, Thales Research and Technology (France); K. Saleh, Lab. d'Analyse et d'Architecture des Systèmes, CNRS, Univ. de Toulouse (France); G. Pillet, L. Morvan, Thales Research and Technology (France); O. Llopis, Lab. d'Analyse et d'Architecture des Systèmes, CNRS, Univ. de Toulouse (France); D. Dolfi, Thales Research and Technology (France)

862400 Continuous wave terahertz reflection imaging of human colorectal tissue [8624-23] P. Doradla, The Univ. of Massachusetts Lowell (United States); K. Alavi, The Univ. of Massachusetts Medical School (United States); C. S. Joseph, R. H. Giles, The Univ. of Massachusetts Lowell (United States)

THZ AND MM-WAVE CONDUCTIVITY, DETECTORS, RELATED MEASUREMENTS, AND TECHNIQUES

$8624 \mathrm{OQ}$ Millimeter and terahertz detectors based on plasmon excitation in InGaAs/InP HEMT devices [8624-25]

N. Nader Esfahani, Univ. of Central Florida (United States) and Solid State Scientific Corp. (United States); R. E. Peale, Univ. of Central Florida (United States); W. R. Buchwald, Solid State Scientific Corp. (United States) and Univ. of Massachusetts Boston (United States); J. R. Hendrickson, J. W. Cleary, Air Force Research Lab. (United States)

8624 OT Frequency, amplitude, and phase measurements of $\mathrm{GHz}$ and $\mathrm{THz}$ sources using unstabilized THz frequency combs [8624-28]

H. Füser, M. Bieler, Physikalisch-Technische Bundesanstalt (Germany)

RF TO THZ MATERIALS, TECHNIQUES, TECHNOLOGY AND SOURCES, DETECTION AND DEVICES I

$8624 \mathrm{OU}$ Fabrication and characterization of suspended graphene membranes for miniature Golay cells (Invited Paper) [8624-29]

E. Ledwosinska, McGill Univ. (Canada); A. Guermoune, M. Siaj, Univ. du Québec à Montréal (Canada) and Univ. Laval (Canada); T. Szkopek, McGill Univ. (Canada) and Univ. de Montréal (Canada)

8624 OV Design and fabrication of an RF GRIN lens using 3D printing technology [8624-30]

J. W. Allen, B.-I. Wu, Air Force Research Lab. (United States)

8624 OW An FBG sensor interrogation technique based on a precise optical recirculating frequency shifter driven by RF signals [8624-31]

Z. Wang, T. Yang, D. Jia, Z. Wang, M. Sang, Tianjin Univ. (China) 
8624 OY Progress towards dual vertical slot modulator for millimeter wave photonics [8624-33]

S. T. Kozacik, M. Murakowski, M. Konkol, S. Addya, D. L. K. Eng, B. C. Olbricht, M. J. Zablocki, The Univ. of Delaware (United States); A. Sharkawy, EM Photonics, Inc. (United States);

J. Murakowski, S. Shi, D. W. Prather, The Univ. of Delaware (United States)

$8624 \mathrm{OZ}$ Flat pulse-amplitude rational-harmonic-mode-locking fiber lasers with $\mathrm{GHz}$ pulse repetition rates [8624-34]

T. Wang, T. Yang, D. Jia, Z. Wang, M. Sang, Tianjin Univ. (China); N. Bai, G. Li, CREOL, The

College of Optics and Photonics, Univ. of Central Florida (United States)

METAMATERIALS AND RELATED MATERIALS

862410 Metamaterial films as narrowband terahertz emitters [8624-35]

B. Kearney, F. Alves, D. Grbovic, G. Karunasiri, Naval Postgraduate School (United States)

862411 High sensitivity metamaterial based bi-material terahertz sensor [8624-36]

F. Alves, D. Grbovic, B. Kearney, G. Karunasiri, Naval Postgraduate School (United States)

862412 Numerical simulation of terahertz plasmons in gated graphene structures [8624-37]

A. Satou, V. Ryzhii, Tohoku Univ. (Japan); F. T. Vasko, V. V. Mitin, Univ. at Buffalo (United

States); T. Otsuji, Tohoku Univ. (Japan)

\section{RF TO THZ TRANSMISSION, SENSORS, SOURCES, AND DETECTION}

862413 Efficient horn antennas for next-generation terahertz and millimeter-wave space telescopes [8624-39]

D. McCarthy, N. Trappe, A. Murphy, C. Bracken, S. Doherty, M. L. Gradziel, C. O'Sullivan, National Univ. of Ireland, Maynooth (Ireland)

862414 Low-loss waveguides for THz guidance and devices [8624-40]

B. M. A. Rahman, C. Themistos, H. Tanvir, M. Uthman, A. Quadir, C. Markides, City Univ. London (United Kingdom)

862415 Ultra-broadband wavelength conversion sensor using thermochromic liquid crystals [8624-41]

I. A. Chen, North Carolina State Univ. (United States); S. W. Park, G. Chen, C. Wang, Stevens Institute of Technology (United States); C. Bethea, Quantum Technology Consultants Inc. (United States); R. Martini, Stevens Institute of Technology (United States);

D. Woolard, North Carolina State Univ. (United States) 
862416 Antenna-coupled heterostructure field effect transistors for integrated terahertz heterodyne mixers [8624-42]

A. Di Gaspare, Istituto di Fotonica e Nanotecnologie, CNR (Italy); V. Giliberti, Istituto di Fotonica e Nanotecnologie, CNR (Italy) and Univ. degli Studi di Roma La Sapienza (Italy); R. Casini, E. Giovine, Istituto di Fotonica e Nanotecnologie, CNR (Italy); F. Evangelisti, Univ. degli Studi di Roma Tre (Italy); D. Coquillat, Lab. Charles Coulomb, CNRS, Univ. Montpellier 2 (France); W. Knap, Institute of High Pressure Physics (Poland); S. Sadofev, R. Calarco, Paul-Drude-Institut für Festkörperelektronik (Germany); M. Dispenza, C. Lanzieri, Selex Sistemi Integrati S.p.A. (Italy); M. Ortolani, Istituto di Fotonica e Nanotecnologie, CNR (Italy) and Univ. degli Studi di Roma La Sapienza (Italy)

862417 Realization of an ultra-broadband voltage pulse standard utilizing time-domain optoelectronic techniques [8624-43]

M. Bieler, H. Füser, Physikalisch-Technische Bundesanstalt (Germany)

RF TO THZ MATERIALS, TECHNIQUES, TECHNOLOGY AND SOURCES, DETECTION AND DEVICES II

862418 Electric field sensor based on electro-optic polymer refilled silicon slot photonic crystal waveguide coupled with bowtie antenna [8624-44]

$X$. Zhang, The Univ. of Texas at Austin (United States); A. Hosseini, Omega Optics, Inc. (United States); X. XU, The Univ. of Texas at Austin (United States); S. Wang, Q. Zhan, The Univ. of Dayton (United States); Y. Zou, The Univ. of Texas at Austin (United States);

S. Chakravarty, Omega Optics, Inc. (United States); R. T. Chen, The Univ. of Texas at Austin (United States)

862419 Technological customization of uncooled amorphous silicon microbolometer for $\mathrm{THz}$ real time imaging [8624-45]

S. Pocas, E. Deronzier, P. Brianceau, P. Imperinetti, G. Dumont, A. Roule, W. Rabaud, J. Meilhan, F. Simoens, V. Goudon, C. Vialle, A. Arnaud, CEA-LETI-Minatec (France)

POSTER SESSION

8624 1C Tunable THz wave transmission using liquid metal based devices [8624-48]

R. Zhou, J. Cheng, Y. Lin, H. Zhang, Univ. of North Texas (United States)

Author Index 


\section{Conference Committee}

Symposium Chair

David L. Andrews, University of East Anglia Norwich (United Kingdom)

Symposium Cochairs

Alexei L. Glebov, OptiGrate Corporation (United States)

Klaus P. Streubel, OSRAM GmbH (Germany)

Program Track Chair

James G. Grote, Air Force Research Laboratory (United States)

Conference Chairs

Laurence P. Sadwick, InnoSys, Inc. (United States)

Créidhe M. O'Sullivan, National University of Ireland, Maynooth (Ireland)

Conference Program Committee

Antao Chen, University of Washington (United States)

Robert H. Giles, University of Massachusetts Lowell (United States)

R. Jennifer Hwu, InnoSys, Inc. (United States)

Anthony Murphy, National University of Ireland, Maynooth (Ireland)

Michael C. Wanke, Sandia National Laboratories (United States)

Tianxin Yang, Tianjin University (China)

\section{Session Chairs}

1 Silicon Photonics Meets EO-Polymers: Joint Keynote Session with Conferences 8622, 8624, and 8629

Robert A. Norwood, College of Optical Sciences, The University of Arizona (United States)

2 THz Topics and Advancements

Tianxin Yang, Tianjin University (China)

Laurence P. Sadwick, InnoSys, Inc. (United States)

$3 \mathrm{THz}$ and Submillimeter Generation and Sources

Robert H. Giles, University of Massachusetts Lowell (United States)

Laurence P. Sadwick, InnoSys, Inc. (United States) 
4 THz Smart Materials and Imaging

Darragh McCarthy, National University of Ireland, Maynooth (Ireland) Laurence P. Sadwick, InnoSys, Inc. (United States)

5 RF Devices, Sources, and Components

Tianxin Yang, Tianjin University (China)

Laurence P. Sadwick, InnoSys, Inc. (United States)

6 Continous Wave Sources, Devices, Techniques, and Technology

Robert H. Giles, University of Massachusetts Lowell (United States)

Laurence P. Sadwick, InnoSys, Inc. (United States)

$7 \mathrm{THz}$ and MM-Wave Conductivity, Detectors, Related Measurements, and Techniques

R. Jennifer Hwu, InnoSys, Inc. (United States)

Laurence P. Sadwick, InnoSys, Inc. (United States)

8 RF to THz Materials, Techniques, Technology and Sources, Detection and Devices I

Antao Chen, University of Washington (United States)

Laurence P. Sadwick, InnoSys, Inc. (United States)

9 Metamaterials and Related Materials

Tianxin Yang, Tianjin University (China)

Laurence P. Sadwick, InnoSys, Inc. (United States)

10 RF to THZ Transmission, Sensors, Sources, and Detection

Michael C. Wanke, Sandia National Laboratories (United States)

Laurence P. Sadwick, InnoSys, Inc. (United States)

11 RF to THz Materials, Techniques, Technology and Sources, Detection and Devices II

Darragh McCarthy, National University of Ireland, Maynooth (Ireland) Laurence P. Sadwick, InnoSys, Inc. (United States) 


\section{Introduction}

The 2013 Terahertz, RF, Millimeter, and Submillimeter-Wave Technology and Applications VI Conference was divided into eleven sessions reflecting specific categories as follows; Session 1-Silicon Photonics Meets EO-Polymers: Joint Keynote Session with Conferences 8622, 8624, and 8629; Session 2-THz Topics and Advancements; Session 3-THz and Submillimeter Generation and Sources; Session 4-THz Smart Materials and Imaging; Session 5-RF Devices, Sources, and Components; Session 6-Continuous Wave Sources, Devices, Techniques, and Technology; Session 7-THz and MM-Wave Conductivity, Detectors, Related Measurements, and Techniques; Session 8-RF to THz Materials, Techniques, Technology and Sources, Detection and Devices I; Session 9-Metamaterials and Related Materials; Session 10-RF to $\mathrm{THz}$ Transmission, Sensors, Sources, and Detection; and Session 11-RF to THz Materials, Techniques, Technology and Sources, Detection and Devices II.

Session 1 was a joint session on photonic circuits, organic and plastic photocells and other optoelectronic devices.

Session 2 began with an invited talk by Professor Elliott Brown covering a powerful new $\mathrm{THz}$ photoconductive source driven at $1550 \mathrm{~nm}$, followed by an invited talk by Dr. Zachary Taylor on $\mathrm{THz}$ imaging using broadband direct detection and a contributed talk on strong optical forces in the mid-IR and terahertz mediated by coupled spoof surface plasmons.

Session 3 began with an invited paper on the microfabrication and cold testing of copper circuits for a 50-watt $220-\mathrm{GHz}$ traveling wave tube from the US Naval Research Laboratory and also included contributed papers on a tunable continuous-wave terahertz generator based on $1.3 \mu \mathrm{m}$ dual-mode laser diode and travelling-wave photodiode, a tunable continuous-wave terahertz generator based on $1.3 \mu \mathrm{m}$ dual-mode laser diode and travelling-wave photodiode, room temperature generation of $\mathrm{THz}$ radiation in GaN quantum wells structures, and an improved design of $\mathrm{THz}$ radiation device with hybrid waveguide structures compatible with latest technique of monolithic integration fabrication.

Session 4 began with an invited paper by Professor Tianxin Yang on precise manipulation of light properties in optical domain by RF technology followed by a talk on terahertz time-domain spectroscopy of organic semiconductors, a talk on 3D terahertz beam profiling, followed by a talk on imaging at 0.2 and 2.5 terahertz, and concluding with a talk on new developments in a 384x288 pixel terahertz camera core.

Session 5 began with an invited paper on millimeter-wave and sub-millimeterwave vacuum electronics amplifier development at the US Naval Research 
Laboratory given by Doctor David Abe of the US Naval Research Laboratory, followed by a talk on integrated RF photonic devices based on crystal ion sliced lithium niobate, continuing with a talk on IMDD microwave photonic link modeling using Optsim, and concluding with a talk on a progress toward a widely tunable narrow linewidth RF source utilizing an integrated heterogenous silicon photonic module.

Session 6 began with a talk on widely tunable opto-electronic oscillator based on a dual frequency laser, followed by talks that included a continuous wave terahertz reflection imaging of human colorectal tissue.

Session 7 began with a talk on Millimeter and terahertz detectors based on plasmon excitation in InGaAs/InP HEMT devices, followed by talks dealing with the topic of conductivities.

Session 8 began with an invited talk on the fabrication and characterization of suspended graphene membranes for miniature Golay cells by Elizabeth Ledwosinska, the invited talk was followed by talks on the design and fabrication of an RF GRIN lens using 3D printing technology, an FBG sensor interrogation technique based on a precise optical recirculating frequency shifter driven by RF signals, an enhanced terahertz emission from photoconductive emitters using plasmonic contact electrodes, a talk on the progress being made toward dual vertical slot modulator for millimeter wave photonics, and concluding with a talk on flat pulse-amplitude rational-harmonic-mode-locking fiber lasers with $\mathrm{GHz}$ pulse repetition rates.

Session 9 began with a talk on metamaterial films as narrowband terahertz emitters, followed by a talk on a high sensitivity metamaterial based bi-material terahertz sensor, and concluding with a talk on the numerical simulation of terahertz plasmons in gated graphene structures.

Session 10 began with a talk on efficient horn antennas for next-generation terahertz and millimeter-wave space telescopes, and included a talk on antenna-coupled heterostructure field effect transistors for integrated terahertz heterodyne mixers, and concluded with a realization of an ultra-broadband voltage pulse standard utilizing time-domain optoelectronic techniques.

Session 11 began with a talk on electric field sensor based on electro-optic polymer refilled silicon slot photonic crystal waveguide coupled with bowtie antenna, followed by a talk on technological customization of uncooled amorphous silicon microbolometer for $\mathrm{THz}$ real time imaging, and included a talk on the generation of frequency tunable and broadband $\mathrm{THz}$ pulses in the frequency range 1-20 THz with organic electro-optic crystals OHI and DSTMS.

As in prior Terahertz Technology and Applications Conferences, these papers represent a cross section of much of the research work that is being pursued in 
the technically challenging terahertz spectral region. The Conference now includes talks and topics covering the Terahertz, RF, Millimeter, and SubmillimeterWave frequency regions as well as related and associated technologies. In the prior five years of the proceedings of this conference (Conferences 6472, 6893 7215, 7601, 7938, and 8261, respectively), we (including Doctror Kurt Linden) presented a list of recent technical articles describing significant advances in the terahertz technology. This year, for the interested reader, we also include a list that points to a rather extensive and growing database on the terahertz absorption characteristics of a large number of chemicals given on the website www.thzdb.org. That website, in turn, provides links to related terahertz technology database websites as shown in Table 1.

Table 1. List of terahertz technology database websites as found at www.thzdb.org

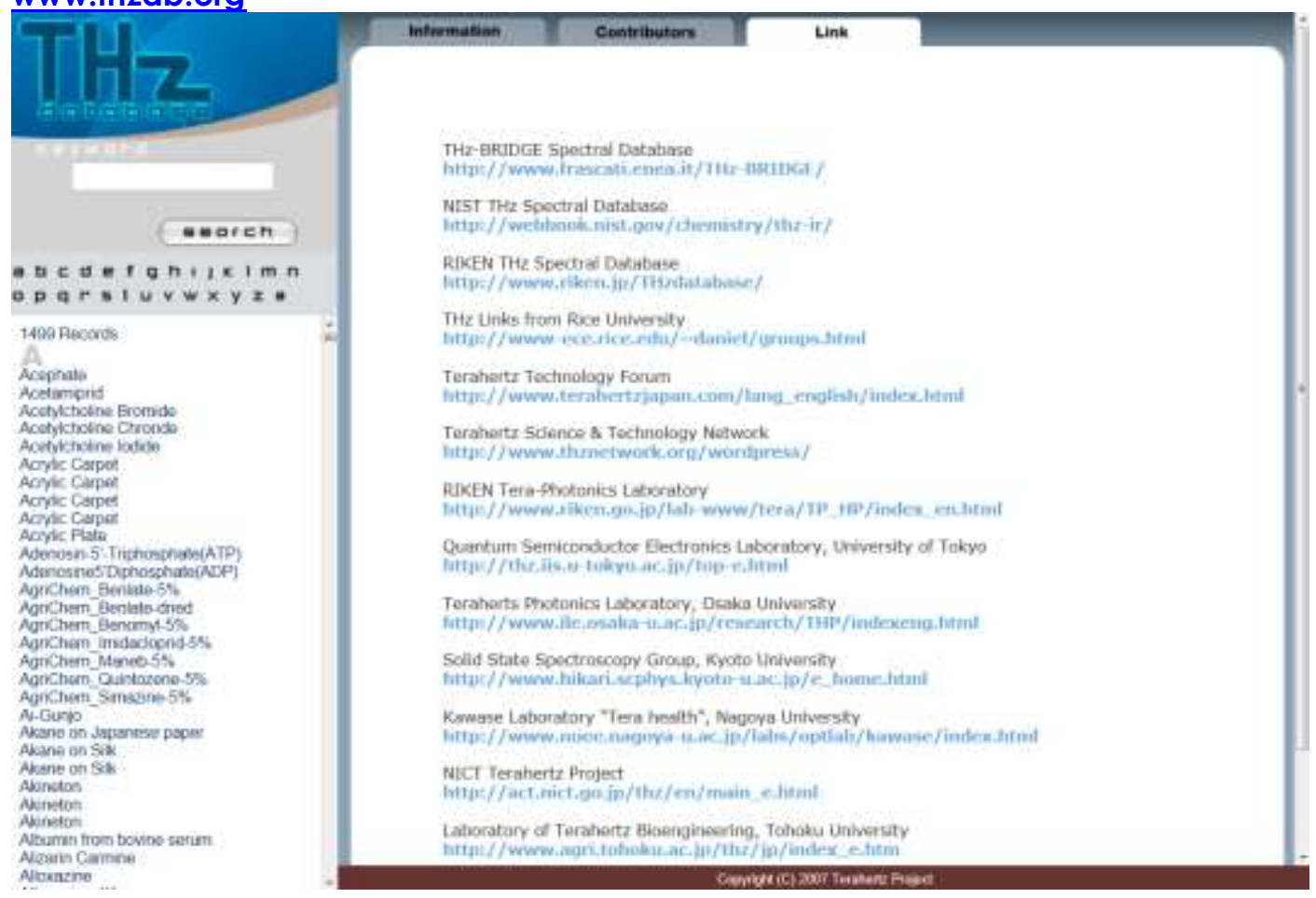

In the last five years' introduction to SPIE Proceedings, Volumes 6893, 7215, 7601, 7938, and 8261 respectively, two tables were included, one summarizing the more common terahertz radiation sources, and the other summarizing the more common terahertz detector types. For the interest of the general reader we again include these tables without updates other than to note that recent advancements in vacuum electronics BWOs coupled with solid state multipliers have now produced usable power above $2 \mathrm{THz}$ and that devices such as quantum cascade lasers continue to make improvements that encroach upon 
established high power sources such as carbon dioxide lasers. Due to such advancements, any values listed in Tables 2 and 3 are likely to be bested by new records in a very short time period; however the sources and detectors listed in Tables 2 and 3 still comprise the majority of those used in the $\mathrm{THz}$ regime. Readers of this volume may send additions and enhancements to these tables so that future volumes can continue to provide readers with relevant information on the availability of terahertz sources and detectors. Such suggestions can be sent to sadwick@innosystech.com.

\section{Table 2. Summary of common terahertz sources}

\begin{tabular}{|c|c|c|}
\hline THz source type & Details & Characteristics \\
\hline \multirow[t]{2}{*}{ Synchrotron } & ${ }^{*}$ Coherent synchrotron produces very high & E-beam, very broadband source, limited instrument \\
\hline & photon flux, including $\mathrm{THz}$ region & availability, very large size, $20 \mathrm{~W}$ pulsed \\
\hline \multirow[t]{2}{*}{ Free electron laser } & * Benchtop design at Univ. Essex, UK & Tunable over entire $\mathrm{THz}$ region, under development \\
\hline & Elec beam moves over alternate $\mathrm{H}$-field regions & $0.1-4.8 \mathrm{THz}, 0.5-5 \mathrm{~kW}, 1-20$ us pulses at $1 \mathrm{~Hz}$ \\
\hline Smith-Purcell emitters & * E-beam travels over metal grating surface, & Requires vacuum, has low efficiency \\
\hline \multirow[t]{2}{*}{ Backward-wave oscillators } & ${ }^{*}$ Vacuum tube, requires homog $\mathrm{H}$-field $\sim 10 \mathrm{kG}$ & Tunable output possible. Under development and \\
\hline & "Carcinotron", room temperature, to $1.2 \mathrm{Thz}$ & commercially available, $10 \mathrm{~mW}$ power level, $<1 \mathrm{THz}$ \\
\hline \multirow[t]{2}{*}{ Mercury lamp } & ${ }^{*}$ Water cooled housing, low press. $1 \mathrm{E}-3$ Torr & Sciencetech SPS-200,300, low power density \\
\hline & 75-150 W lamp, broad emission & Low-cost, used in THz spectroscopy \\
\hline \multirow[t]{2}{*}{ Optically pumped gas cell laser } & ${ }^{*}$ Grating-tuned CO2 laser and far-IR gas & $>100 \mathrm{~mW}, 0.3-10 \mathrm{THz}$, discrete lines, CW/pulsed \\
\hline & cell such as methane. Most mature laser. & Commercially avail - Coherent $(\$ 400 \mathrm{~K}-\$ 1 \mathrm{M})$ \\
\hline \multirow{3}{*}{$\begin{array}{l}\text { Opt pump GaAs, p-InAs, Si, ZnTe, } \\
\text { InGaAs (fiber laser pump), Ge } \\
\text { photoconducting (PC) switch }\end{array}$} & ${ }^{*}$ Mode locked Nd:YAG or Ti:sapphire laser & Imaging apparatus produced, 0.1 to $3 \mathrm{THz}$ \\
\hline & creates short across biased spiral antenna gap & Commercially available, $\mathrm{CW}$ uW range, $\$ 50 \mathrm{~K}-500 \mathrm{~K}$ \\
\hline & ${ }^{*}$ Also As-doped Si, CO2 laser pump & $6 \mathrm{THz}$ stim emission from As, Liq He temp. \\
\hline \multirow[t]{2}{*}{ Laser-induced air plasma } & ${ }^{*}$ Ti-saph laser induces air plasma & Remote $\mathrm{THz}$ generatiion possible, very low power \\
\hline & & Possibility of power increase in multiple plasmas \\
\hline \multirow[t]{5}{*}{ Photomixing of near-IR lasers } & ${ }^{*}$ Mixing tunable Ti-sapphire laser and diode & Tens of nW, tunable. Requires antenna pattern \\
\hline & laser in LT-grown GaAs photomixer. & Not commercial. GaP gave $480 \mathrm{~mW} @ 1.3 \mathrm{THz}$ \\
\hline & * GaSe crystal, Nd:YAG/OPO difference freq & Tunable 58-3540um (5-0.1THz),209 W pulse 1.5THz \\
\hline & * Single $835 \mathrm{~nm}$ diode laser, external cavity & 2-freq mix\& 4-wave mixing, RT, sub-nW,0.3-4.2THz \\
\hline & * Diff-freq generation with 2 monolith QCLs & $7.6 \mathrm{u} \& 8.7 \mathrm{u} \rightarrow 5 \mathrm{THz}, 60 \mathrm{nW}$ puled output \\
\hline \multirow[t]{2}{*}{ Electrically pumped $\mathrm{Ge}$ in $\mathrm{H}$-field } & * Electric field injects electrons, magnetic & Requires electric and magnetic fields Output up to \\
\hline & field splits hole levels for low-E transitions & hundres of $\mathrm{mW}$, cryogenic cooling, $1.5 \sim 4 \mathrm{THz}$ \\
\hline \multirow[t]{2}{*}{ Electrically pumped Si:B or As } & * Transitions between impurity levels & 31 uW output at $8.1 \mathrm{THz}$, slightly polarized \\
\hline & $100 \times 200$ um rectangle mesas, biased & Cryogenic cooling needed \\
\hline \multirow[t]{2}{*}{ Electrically pulsed InGaAs RTD } & ${ }^{*}$ Harmonically generated by electrical pulses & $0.6 \mathrm{uW}, 1.02 \mathrm{THz}$ harmonic from InGaAs/AIAs RTD \\
\hline & RTD integrated into slot antenna & pulsed at $300 \mathrm{~Hz}$ \\
\hline \multirow[t]{2}{*}{ Direct multiplied $\mathrm{mm}$ waves } & ${ }^{*}$ Multiplied to low-THz region & Low power (uW level), available (VA Diodes) \\
\hline & up-multiplied from $\mathrm{mm}$-wave & Coherent, heterodyne local oscillators in astronomy \\
\hline \multirow[t]{2}{*}{ Parametric generators } & * Q-switched Nd:YAG pumps MgO:LiNbO3 & $200 \mathrm{~W}$ pulsed power, room temp., 0.1-5 THz tunable \\
\hline & non-linear crystal, Phase matched GaAs, GaP & some commercially available $\sim \$ 30 \mathrm{~K}$ \\
\hline \multirow[t]{2}{*}{ Quantum cascade $(\mathrm{QC})$ laser } & * First announced in 2002, semiconductor, & Operated at $\mathrm{mW}$ power, and up to $164 \mathrm{~K}$ pulsed \\
\hline & AlGaAs/GaAs-based, MBE grown, 1.6 to $4 \mathrm{THz}$ & THz not commercially available, require cryo-cooling \\
\hline Josephson junction cascades & Research stage & 0.4-0.85 THz, microwatts \\
\hline \multirow[t]{2}{*}{ Transistor } & ${ }^{*}$ InGaAs channel PHEMT with $35 \mathrm{~nm}$ gate & 1.2 THz, development at Northrop Grumman \\
\hline & * InGaAs with $12.5 \mathrm{~nm}$ gate, $0.845 \mathrm{THz}$ & Univ. III (Dec 2006) \\
\hline Grating-bicoupled plasmon-FET & * GaAs based double interdigitated grating & with 1.5um laser illum., Tohoku/Hokkaido Univ. \\
\hline
\end{tabular}




\section{Table 3. Summary of common terahertz radiation detectors}

\begin{tabular}{|c|c|c|}
\hline THz detector type & Details & Characteristics \\
\hline \multirow[t]{2}{*}{ Si bolometer } & * Most sensitive (10 pW Hz1/2) THz detector & Responsivity 2E9V/W,NEP=1E-17 WHz1/2,100 mK \\
\hline & at liquid He temp., slow response time & Requires liquid He dewar, commercially avail. \\
\hline \multirow[t]{2}{*}{ Superconducting hot elec bolom } & * Highest sensitivity & Requires cooling to $0.3 \mathrm{~K}, \mathrm{NEP}=1 \mathrm{E}-17 \mathrm{WHz} 1 / 2$ \\
\hline & Fast (1 us) response time & Commercially available, expensive, bulky \\
\hline \multirow[t]{2}{*}{ Pyroelectric detectors } & ${ }^{*}$ Slow response t, $220 \mathrm{nW}$ sensitiv at $24 \mathrm{~Hz}$ & Room temp operation, commercially available, \\
\hline & Requires pulsed signals or mechanical chopper & Low cost, imagers available $\sim \$ 10 \mathrm{~K}$ \\
\hline \multirow[t]{2}{*}{ Schottky diodes } & * $\sim 1 \mathrm{THz}$ cutoff frequency & Commercially available ((VA Diodes) with corner ref. \\
\hline & Fast response, but low $\mathrm{THz}$ sensitivity & Room temp operation, good for mixers \\
\hline \multirow[t]{2}{*}{ PC dipole antennas } & * signal gen across biased spiral antenna gap & Analogous to optically pumped THz PC switch but \\
\hline & Short pulsed detection only & in detection mode. Commercially available \\
\hline Antenna coupled inter-subband & * 4-terminal phototransistor, $1.6 \mathrm{THz}$ & Under development UCSB \\
\hline \multirow[t]{2}{*}{ III-V HEMT \& Si FET to $300 \mathrm{~K}$} & * HEMT with $250 \mathrm{~nm}$ gate & $20 \mathrm{~K}, 50 \mathrm{mV} / \mathrm{W}$ at $420 \mathrm{GHz}$, still in development \\
\hline & plasma wave-based detection & Univ research, Si NEP to $1 \mathrm{E}-10 \mathrm{~W} / \mathrm{Hz} 1 / 2$ at $300 \mathrm{~K}$ \\
\hline \multirow[t]{2}{*}{ Quantum dot photon detector } & ${ }^{*}$ Demo-photon counting terahertz microscopy & Under development, $1 \mathrm{E}-19 \mathrm{~W}=100$ photons/sec, \\
\hline & imaging, requires $0.3 \mathrm{~K}$ temp, research only & Tokyo Univ. \\
\hline
\end{tabular}

Laurence P. Sadwick Creidhe M. M. O'Sullivan 